\title{
Zeolite, Study of Aptitude as a Natural Pozzolan Applied to Structural Concrete
}

Zeolita, Estudio de Aptitud como una Puzolana Natural Aplicada a Hormigón Estructural

Bárbara Belén Raggiotti(Main Author) (Contact Author) CINTEMAC. Universidad Tecnológica Nacional. Facultad Regional Córdoba. Argentina.

Maestro M. López esq. Cruz Roja Argentina - Ciudad Universitaria, Córdoba, Argentina +54-0351-598-6000 / 598-6001.

belenraggiotti@gmail.com

\section{María Josefina Positieri}

CINTEMAC. Universidad Tecnológica Nacional. Facultad Regional Córdoba. Argentina.

mpositieri@gmail.com

\author{
Francisco Locati \\ CICTERRA (CONICET - UNC), Córdoba, Argentina. \\ flocati@efn.uncor.edu \\ Juan Murra \\ CICTERRA (CONICET - UNC), Córdoba, Argentina. \\ jmurra@com.uncor.edu \\ Silvina Marfil \\ CICTERRA (CONICET - UNC), Córdoba, Argentina. \\ smarfil@uns.edu.ar
}

\author{
Manuscript Code: 217 \\ Date of Reception/Acceptance: 30.05.2014/01.06.2015
}

\begin{abstract}
Resumen
En la actualidad, el hormigón es uno de los materiales de construcción más ampliamente utilizados debido a su bajo precio, apropiadas características mecánicas y de durabilidad, así como por su facilidad de adoptar diversas formas y tamaños (Najimi et al., 2012). Debido a la importancia del uso del hormigón como material estructural de construcción y a su impacto ambiental como consumidor de grandes cantidades de recursos naturales y emisor de $\mathrm{CO} 2$ en la industria del cemento, es necesario desarrollar, desde la ciencia de materiales, mezclas que acompañen el crecimiento de la industria de la construcción considerando el medioambiente; es decir desarrollar materiales energéticamente eficientes. Se estudió una zeolita natural como un material con potencial actividad puzolánica y como reemplazo parcial en distintos porcentajes del cemento pórtland en hormigones estructurales. Los resultados de ensayos mecánicos en hormigones evidencian la factibilidad de utilizar esta adición como material puzolánico.
\end{abstract}

\section{Palabras Claves: Zeolita, Hormigón, Puzolana, Adición Activa, Reemplazo.}

In normal conditions, the production of a ton of Portland clinker requires between 1.5 and 1.6 tons of natural materials that can be burned at high temperatures (approximately 1400 ${ }^{\circ} \mathrm{C}$ ), and this causes a great consumption of non-renewable mineral resources and a serious land degradation in quarrying areas. related to aspects that have to do with economy, ecology and technology. First, the field of economy because they reduce the use of cement, in which a great amount of energy, is used for its production. Second, ecology because by replacing part of the cement, the emission of $\mathrm{CO} 2$ is reduced (compound that contributes to the greenhouse effect); the use of non-renewable resources used in its production is optimized; and also because they constitute a reservoir of many other types of industrial waste. Third, technology since its interactions with the system contribute to the improvement of some of the properties of concrete (Rahhal \& Eperjesi, 2012).

In this report, a natural zeolite from the region of Cuyo in Argentina is proposed as a mineral admixture, which has $\mathrm{SiO} 2$ and $\mathrm{Al} 2 \mathrm{O} 3$ reagents in its composition that contribute to increase the strength of the concrete created by the pozzolanic reaction with the $\mathrm{Ca}(\mathrm{OH}) 2$. Thus, the pozzolanic reactivity of this material is very interesting in the study of sustainable concrete. In this research physico-chemical characterization of the pozzolanic material and mechanical behavior of different concrete mixtures with this material as mineral admixture were studied.

\section{Description of the problem}

The manufacture of concrete implies an important consumption of natural resources and an input of waste that must be eliminated or minimized.
If it is considered that a conventional concrete contains $12 \%$ of cement, $8 \%$ of water and $80 \%$ of aggregates, concrete industry consumes about 1600 million tons of cement (some 2500 million tons of natural materials), 1000 million tons of water and about 11000 million tons of aggregates, which makes a total of 14500 million tons per year of natural resources. This high consumption transforms the industry of concrete in one of the most important users of natural resources of the world. But with the use of cement with high content of additions and the increase in the design ages (and service life) of the structures, the concrete can be transformed into a sustainable material because energy and materials consumption, and its environmental impact are reduced (Bonavetti, 2004).

During the last years, the environment protection and the reduction of manufacturing costs have been topics of discussion in several industries. As consequence, the Portland cement industry has performed changes, promoting the use of supplementary, natural, residual materials or industrial sub products that require less energy for their production. In response to this, and considering the environmental problems, the use of pozzolanic concrete has expanded quickly (Fernández \& Trezza, 2007). If all these changes were implemented, it would be possible to transform the concrete, at least from the point of view of the cement consumption, into a material with sustainable development. 


\section{State of the art}

The use of mineral admixtures in civil construction started before the concrete invention initiated, according to Malhotra and Mehta (1996), in Greece, 1500 year BC with a material of volcanic origin from Santorini Island. These additions spread all over the Roman Empire for the execution of several works (Dal Molin, 2005). Nowadays, the mineral admixtures frequently used are waste, which could be dispersed in great amounts in inadequate places, generating risk of soil and water contamination. (Dal Molin, 2005).

Originally, the term pozzolan was associated with natural volcanic ashes and calcined earth that reacted with lime at room temperature, in a moist environment. Nowadays, the term has been extended to several types of silicon aluminum materials which, finely grounded and in presence of water, can chemically react with the calcium hydroxide $(\mathrm{CH})$ to form compounds that have cement properties, consequently being classified as natural or artificial pozzolans.

Concrete mixtures with zeolite have been widely used in construction since old times. Today, more than 50 natural and 150 synthetic zeolites are known and used in diverse industries. In the cement industry, the natural zeolite is a very popular natural pozzolan in some regions of the world. It is used in great amounts as a pozzolanic material in places like China (Najimi et al., 2012), Iran (Ahmadi \& Shekarchi, 2010) and Cuba (Rosell et al., 2006), among others. In China, it is widely used as an addition to cement and the total amount of zeolite consumed for this purpose is as much as 30 million tons a year (Poon et al., 1999).

\section{Methodology}

The experimental work of this research was divided in two parts. First, the mineral admixture was physically and chemically characterized to determine its activity and application as a pozzolan. In a second stage, different mixes of concrete were design with the incorporation of the mineral admixture in different proportions $(5,10,15$ and $20 \%)$, and tested in fresh and hardened state. In fresh state the consistency was determined through concrete slump test measured with Abrams cone, in accordance with standard IRAM 1536 (1978).

In hardened state, compressive strength at 7, 28, 90 and 180 days in accordance with standard IRAM 1546 (2013) were performed. In addition, splitting tensile test (IRAM 1658, 1995) and elastic modulus at 28 days (ASTM C469, 2014) were carried out. In order to evaluate concrete durability, absorption test (ASTM C642, 2013), capillary suction and capillary suction speed (IRAM 1871, 2004), and air-permeability (SIA 262/1-E, 2003) were also determined in hardened state.

\section{Characterization of the pozzolanic material}

The mineral admixture has a density of $2.13 \mathrm{~g} / \mathrm{cm} 3$ determined by the pycnometer method and a BET specific surface area of $11 \mathrm{~m} 2 / \mathrm{g}$. The sample is granulometrically heterogeneous: $40.62 \%$ of the particles are bigger than $1000 \mu \mathrm{m}$, and $59.38 \%$ of the particles are smaller than or equal to $1000 \mu \mathrm{m}$. The granulometric distribution of the thick and thin fraction can be observed in Table 1 and Figure 1 respectively.

The granulometry was determined by sieving the thick fraction $(\varnothing>1000 \mu \mathrm{m})$, and the thin fraction in sieve $n^{\circ} 18(\varnothing \leq 1000$ $\mu \mathrm{m})$ through a particle size distribution analyzer by laser diffraction (Partica LA-950V2, HORIBA).
Also, the material was analyzed by X-ray diffraction (XRD), $X$-ray fluorescence (XRF), scanning electron microscopy (SEM) equipped with an energy dispersive $X$-ray spectrometer (EDS). The X-ray diffraction study (Figure 2) was performed with a Rigaku D-Max III-C diffractometer, working at $35 \mathrm{kV}$ and 15 $\mathrm{mA}$, using Cu K $\alpha 1,2$ radiation ( $\lambda=1.541840 \AA$ ) filtered through a graphite monochromator in the diffracted beam, between 3 and $60^{\circ} 2 \theta$, in $0.03^{\circ} 2 \theta$ increments with one second counting time per increment.

The quantification of mass fractions of the mineral phases identified by XRD were done by X'Pert High-Score software (PANalytical) using the scale factor and Reference Intensity Ratio (RIR) from the ICDD (International Centre for Diffraction Data) database. Files ICCD 01-083-1260 (clinoptilolite-Na), 01-074-1433 (gypsum), 01-071-1150 (plagioclase), 01-073-1661 (biotite) and 01-075-0443 (quartz) were used.

\begin{tabular}{|c|c|}
\hline Sieve & Retained Material (\%) \\
\hline \#7 (2830 $\mu \mathrm{m})$ & 4.92 \\
\hline \#8 $(2380 \mu \mathrm{m})$ & 3.94 \\
\hline$\# 14(1410 \mu \mathrm{m})$ & 19.38 \\
\hline \#16 (1190 $\mu \mathrm{m})$ & 7.64 \\
\hline$\# 18(1000 \mu \mathrm{m})$ & 4.74 \\
\hline
\end{tabular}

Figure 1. Cumulative and Relative Frequency Curves of the pozzolanic materia that goes through sieve \#18 $(1000 \mu \mathrm{m})$. Source: Self-elaboration, 2014.

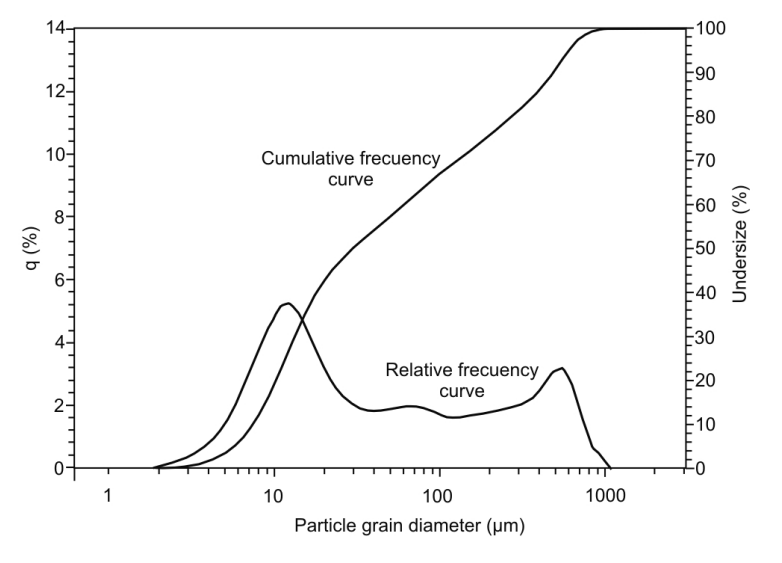

The material corresponds to a mixture of minerals, being the zeolite the predominant phase. In accordance with the identification of minerals by XRD and the semi-quantitative determination of percentage of mineral phases by the RIR method proposed by Chung (1974), the sample is mainly compoused by a zeolite of the clinoptilolite-heulandites series (51\%), gypsum $(13 \%)$, plagioclase $(17 \%)$, biotite $(10 \%)$ and quartz (9\%). Table 2 shows the chemical composition of the mix determined by X-ray fluorescence (XRF).

The zeolite presents itself as small laminated crystals grouped in aggregate rosettes (Figure 3 ) and in accordance to its semi-quantitative composition (Table 3 ) it corresponds to a clinoptilolite $(\mathrm{Si}: \mathrm{Al} \geq 4.0)$ rich in sodium, clinoptilolite-Na (Coombs et al., 1998).

Design of concrete samples with the incorporation of zeolite Two types of concrete were designed as reference, one made with ordinary Portland cement (OPC) and another one made 
with compound Portland cement (CPC). In these concrete samples the amount of cement was replaced by zeolite in the following weight percentages: 5, 10, 15 and $20 \%$. Five concrete samples resulted for each type of cement: the reference mix and four other mixtures with different percentages of cement replacement by zeolite.

In preliminary experiences with concrete that incorporated this zeolite, it was determined that in fresh state, the zeolite had an important influence by reducing the workability of the mixtures. This is the reason why a water reducer plasticizer additive was chosen, since it would allow maintaining the necessary workability without increasing the content of water and consequently, having to increase the water/cement ratio that had been proposed.

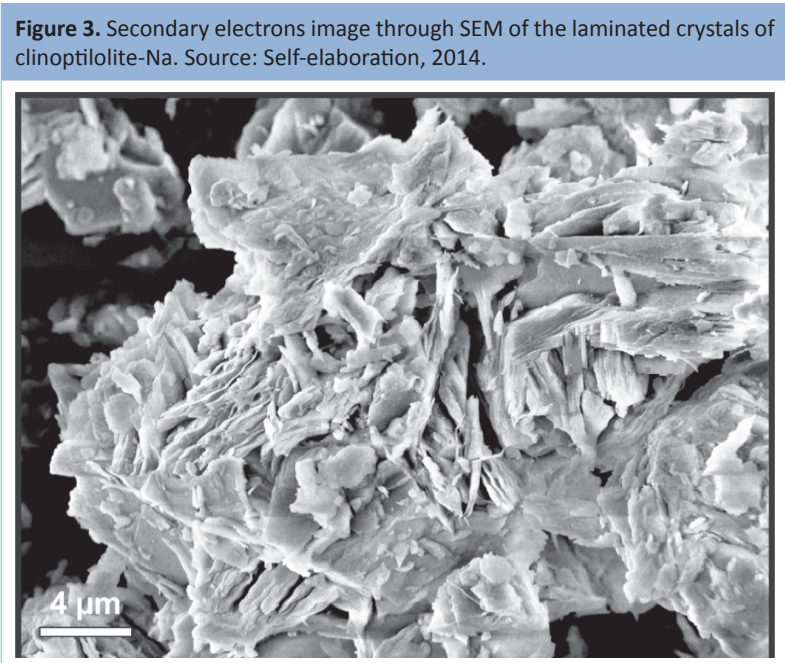

\begin{tabular}{cc}
$\begin{array}{l}\text { Table 3. Semi-quantitative composition (EDS) } \\
\text { Recalculated to } 100 \% \text { considering } 13.5 \% \text { of } \mathrm{H} 2 \mathrm{O}(\mathrm{H} 2 \mathrm{O} \text { average of five analyses }\end{array}$ \\
from Sheppard \& Gude, 1969). Source: Self-elaboration, 2014. \\
\hline Chemical composition & $(\%)$ \\
\hline $\mathrm{SiO} 2$ & 64.9 \\
\hline $\mathrm{Al} 2 \mathrm{O} 3$ & 12.4 \\
\hline $\mathrm{MgO}$ & 0.8 \\
\hline $\mathrm{CaO}$ & 0.6 \\
\hline $\mathrm{Na} 2 \mathrm{O}$ & 5.9 \\
\hline $\mathrm{K} 2 \mathrm{O}$ & 1.9 \\
\hline $\mathrm{H} 2 \mathrm{O}$ & 13.5 \\
\hline $\mathrm{Total}$ & 100.0 \\
\hline
\end{tabular}

Materials

Cements: Ordinary Portland cement (OPC 40) and compound Portland cement (CPC 40) that comply with standard IRAM 50000 (2014) were used. CPC in its composition includes two or more additions, such as pozzolan, slag or calcareous filler up to $35 \%$ according to that standard. The OPC 40 has a compressive strength of $47.3 \mathrm{MPa}$ at 28 days, Blaine specific surface of $3869 \mathrm{~cm} 2 / \mathrm{g}$ and density of $3.15 \mathrm{~g} / \mathrm{cm} 3$. The CPC 40 has a compressive strength of $45.3 \mathrm{MPa}$, Blaine specific surface of $4008 \mathrm{~cm} 2 / \mathrm{g}$ and density of $3.10 \mathrm{~g} / \mathrm{cm} 3$. In addition, values (\%) for material retain on sieve $\# 200$, loss on ignition, insoluble residue and content of $\mathrm{SO} 3$ and $\mathrm{MgO}$ for the OPC are 0.0, 3.74, $2.00,1.65$ and 2.43 , and for the CPC are $0.6,4.00,2.50,2.64$ and 5.50 .
Aggregates: The aggregates have a continuous granulometry and they are within the limit curves, in accordance with standard IRAM 1505 (2005) and 1627 (1997).

The results of the chemical tests indicate that they have no harmful or damaging substances that could affect the concrete. The fine aggregate has a density of $2.66 \mathrm{~g} / \mathrm{cm} 3$, absorption of $0.86 \%$ and a fineness modulus of 3.51 . The coarse aggregate has a maximum size of $19 \mathrm{~mm}$, a density of $2.73 \mathrm{~g} / \mathrm{cm} 3$ and absorption of $1.15 \%$.

Additive: A plasticizer additive of lignosulfonate chemical base was used. The dose used was $0.35 \%$ of the weight of the binding material (cement and zeolite), that is, the same amount of additive was used for all the concrete samples. The additive complies with standard IRAM 1663 (2002) and the requirements of ASTM C494 (2013) for Type A additives, water reducers.

Addition: A mineral admixture from a quarry in the province of La Rioja, Argentina was used as a pozzolanic material. This addition is a mixture of minerals; being the zeolite the predominant phase (51\%). According to its semi-quantitative composition corresponds to a clinoptilolita- $\mathrm{Na}$; a porous aluminosilicate that corresponds to pozzolan type F (ASTM C618, 2012).

Granulometrically the sample is heterogeneous with $11 \mathrm{~m} 2 / \mathrm{g}$ surface area and a density of $2.13 \mathrm{~g} / \mathrm{cm} 3$. Table 4 shows the designation used in the mixtures and the corresponding dosage for a cubic meter of concrete. Designations:

Z: zeolite

O: Ordinary cement

C: Compound cement

Numbers 0, 5, 10, 15 and 20: replacement of cement by zeolite (\%)

\section{Concrete Tests and Analysis of Results}

\section{Fresh state}

Figure 4 shows slump test results. From a rheological point of view, the use of the addition in fresh state improved the cohesion. Due to the low density of the zeolite, the volume of the cement paste was higher than the volume of the cement paste of the reference concrete sample. This increases the contact among solid particles giving the mix more cohesion. On the other hand, as we can see from Figure 4, the mixtures lost consistency after the incorporation of zeolite. This can be attributed to the fact that zeolite is a great cation exchanger, to its porous structure that retains water and to its big specific surface.
Figure 4. Concrete slump test measured with Abrams Cone. Source: Self-elaboration, 2014.

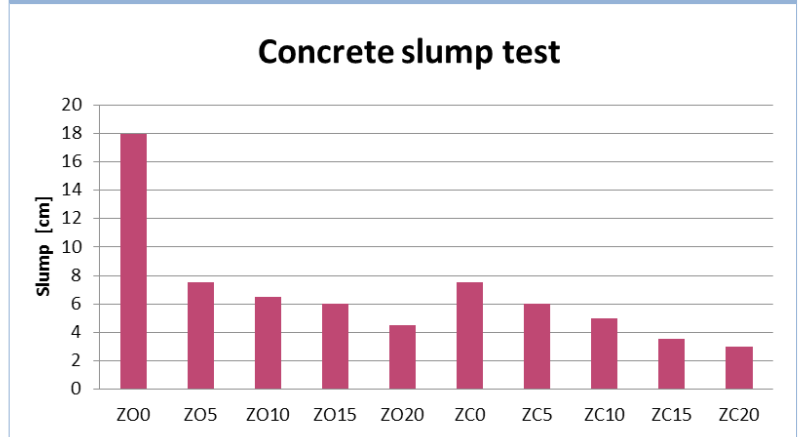


The difference in behavior between mixtures with OPC and CPC is attributed to the composition of the cement. The only mix without any kind of addition, whether in the concrete sample or in the cement was ZOO, and it was the only one that showed higher slump, bringing into light the influence in the workability of the incorporation of additions in the mixtures.

\section{Hardened State}

Figure 5 shows the compressive strength at different ages. The compressive strength of the concrete samples that contain the mineral admixture was lower than the strength obtained with the reference mixtures in almost all ages, but specially in early ages ( 7 and 28 days).

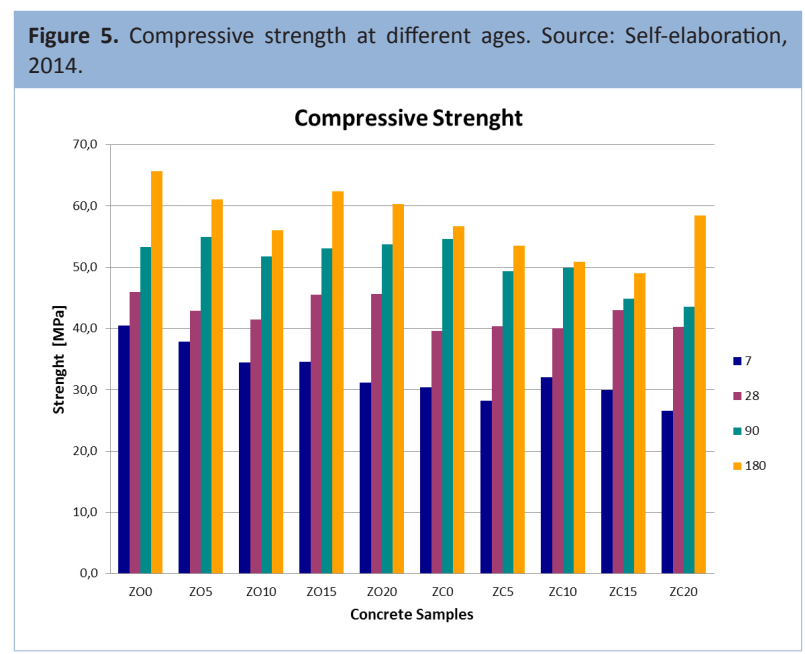

However, the reduction percentages were lower or almost null in higher ages of the concrete samples (90 and 180 days). This can be attributed to the pozzolanic activity of the zeolite. The development of strength in mix ZOO depends mainly on the speed of hydration of the clinker, whereas in the other mixtures it depends on the combination of both the hydration of the clinker and the pozzolanic activity of the zeolite (Perraki et al., 2010).

Figure 5 shows how the concrete samples made with OPC 40 evidence a better performance after compression at all ages than the ones made with CPC 40. This strongly suggests that the composition of the cement used is an important variable when considering the performance of concrete strength.

The lower strength levels reached with CPC 40 are attributed to the lower contents of non-hydrated calcium silicate, capable of reacting with the mineral admixture and therefore creating new hydrated calcium silicate. The silicate that makes up almost the $75 \%$ of OPC has a predominant role in the determination of the hardening characteristics (strength development rate). Table 5 shows the results of the splitting tensile test and elastic modulus test.

In the splitting tensile test the mixtures showed variable behavior, but there was a point in common between both series of different cements. In both cases the mixtures with a $10 \%$ of zeolite showed lower strength to tensile. In the cases in which the mineral admixture content was higher than $10 \%$, the strength was higher. The results from the elastic modulus show a dispersion of 1.26 and 1.94 corresponding to an average of 37.5 and $36.9 \mathrm{GPa}$ for the modulus of OPC and CPC series respectively.
Except for concrete ZC10, mixtures with CPC show that high content of mineral addition produce a more deformable material. In hardened state, the incorporation of the mineral addition causes a loss in the material stiffness. It is worth to consider that the higher the modulus, the stiffer the material. That is, the elastic deformation that originates when applying a specific tension is lower (Callister, 1995). For the CPC series, as the zeolite is incremented, the material turns more deformable, that is, the effort necessary to have equal deformation is lower. Table 6 shows the results of durability tests such as water absorption, capillary suction, capillary suction speed and air permeability.

The air permeability was determined through Permea-TORR equipment. The types of permeability according to this standard are: PK1: very low ( $\mathrm{kT}<0.01)$, PK2: low $(0.01<\mathrm{kT}<$ $0.1)$, PK3: moderate $(0.1<\mathrm{kT}<1.0)$, PK4: high $(1.0<\mathrm{kT}<10.0)$, PK5: very high $(k T>10.0)$.

Mixtures with OPC show two classes of permeability, high and moderate, while CPC series have high air permeability. The incorporation of the mineral admixture generate a more dense structure except in the mixtures with CPC were high values or air permeability were detected. Figure 6 shows the results of capillary suction and capillary suction speed. These tests were performed according to standard procedure IRAM 1871 (2004) but at 90 days of age. The results correspond to measurements after 48 hours of being in contact with water.

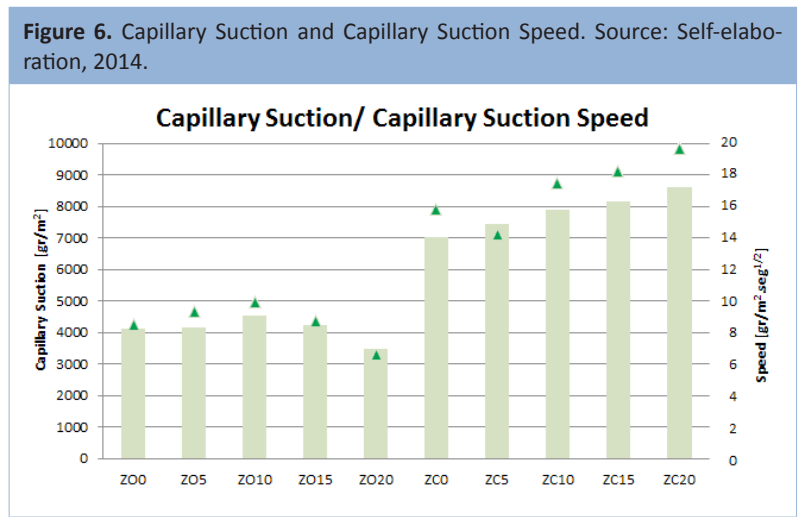

Concrete samples made with OPC show a better behavior than those made with CPC when transporting water through the capillary suction mechanism. This behavior can be related to the results reached in the determination of the absorption showed in Table 6. The composition of samples with OPC is what explains this phenomenon, since the porous structure of the paste only depends on the interaction of ordinary cement with the zeolite, which is not the case in the CPC series, in which there are other mineral admixtures. Concrete samples with OPC and replacements higher than $10 \%$ improve the analyzed properties; mixtures with CPC show an increase in water absorption capacity, when there is a higher replacement of the cement by the mineral admixture. Also, there is a higher capacity of capillary suction and higher capillary suction speed.

\section{Conclusions}

According to physico-chemical characterization of the pozzolanic material it corresponds to a mixture of zeolite (51\%) classified as clinoptilolite- $\mathrm{Na}$, with minor amount of gypsum $(13 \%)$, plagioclase $(17 \%)$, biotite $(10 \%)$ and quartz (9\%). Although it does not fit exactly the maximum limit of $\mathrm{SO} 3$ for type F pozzolan described in standard ASTM C618 (2012), 
it can be used as a material with pozzolanic characteristics in mixtures of Portland cement according to the results from mechanic strength and durability tests performed.

The rough and porous texture of the zeolite, as well as its great superficial area, make a paste structure that contains more complex forms and voids than the reference matrix mix, caused by the growth of the crystalline structure in all directions (Yllmaz et al., 2007). This phenomenon is expressed in a loss of consistency in the mixtures when the incorporation of zeolite is higher, as was observed in the Abrams cone test.

In relation to the results of the mechanical tests, the use of zeolite makes a contribution to the development of strength in the concrete samples over time, displaying its activity in ages higher than 28 days. It is important to note the difference in behavior obtained in relation to the type of cement used, mainly when durability indicators are analyzed. When CPC were used, more "porous" mixes were found.

Experimentally, this higher porosity is evident from the results in Table 6, where a greater degree of capillary porosity and connectivity of the pores and capillaries were seen in mixtures with CPC. The importance of the cement composition and the interaction and reaction with the zeolite, are evidenced especially for replacements of 15 and $20 \%$.

The durability properties of the concrete with OPC were achieved satisfactorily when 15 and $20 \%$ of zeolite were used, while for minor replacements the results were similar to those achieved by the reference mixture. For the concretes with CPC the best results were obtained for small replacements ( 5 and $10 \%)$. As expected, the best effectiveness of the application of zeolite was observed in mixtures with OPC, given that the CPC already has other additions in its composition.

Finally, it is worth noticing that natural zeolites have different chemical properties depending on their origin, this is why it is necessary to make a careful characterization before using them as additives in cement mixtures. The zeolite used in this work, clinoptilonite- $\mathrm{Na}$, performed the three functions for which an additive is necessary in Portland cement mixtures. An economic function, since the amount of cement was reduced in the mixtures; an ecologic function, since an available material was used (a material that is not used for any other purpose in the market and that otherwise would keep being accumulated, becoming a waste product from the mining industry); and a technological function, since it improved the properties of concrete. Therefore, the mineral admixture (with 51\% of zeolite) studied in this research can be used as a pozzolanic material in structural concrete improving its properties.

As Uzal and Turanli (2012) found in their recent studies, the clinoptilolite zeolite can have reactivity comparable to the silica fume, higher than the fly ash and a non-zeolitic natural pozzolan. In this research, it was determined that the studied clinoptilonite- $\mathrm{Na}$ presents a good pozzolanic activity, as evidenced through the results obtained.

The best performance was achieved by the concrete with a replacement of $20 \%$ of OPC for zeolite. Strength results obtained were similar and comparable to the reference concrete, and the results of durability were better than the standard mixture. In addition, this percentage of replacement (20\%) implies a lower use of cement, meaning a concrete contribution to the conservation of the environment.

\section{Acknowledgements}

The authors thank CINTEMAC (UTN-FRC), CICTERRA (CONICETUNC), the Geology Department of UNS-INGEOSUR and CIC of the Province of Buenos Aires for their support. We also thank the Secretary of Science Technology and Postgraduate Studies of the National Technological University for the doctoral scholarship to Eng. Belén Raggiotti. Financial support was provided by UTN2064 Project (UTN - FRC), FONCyT Project PICT 2014-2483 and SECYT-UNC. 
Ahmadi, B. \& Shekarchi, M. (2010). Use of natural zeolite as a supplementary cementitious material. Cement and Concrete Composites, 32(2), 134-141. doi:10.1016/j. cemconcomp.2009.10.006.

ASTM C469/C469M. (2014). Standard Test Method for Static Modulus of Elasticity and Poisson's Ratio of Concrete in Compression. ASTM: Philadelphia, United States.

ASTM C494/C494M. (2013). Standard Specification for Chemical Admixtures for Concrete. ASTM: Philadelphia, United States.

ASTM C618. (2012). Standard Specification for Coal Fly Ash and Raw or Calcined Natural Pozzolan for Use in Concrete. ASTM: Philadelphia, United States.

ASTM C642. (2013). Standard Test Method for Density, Absorption, and Voids in Hardened Concrete. ASTM: Philadelphia, United States.

Bonavetti, V. L. (2004). Hormigones con alto contenido de adiciones. En Irassar, E. F. (Ed.), Hormigones especiales (pp. 97-142). Buenos Aires: AATH.

Callister, W. D. Jr. (1995). Introducción a la Ciencia e Ingeniería de los Materiales. Barcelona: Editorial Reverté.

Chung, F. H. (1974). Quantitative interpretation of X-ray diffraction patterns of mixtures. I. Matrix-flushing method for quantitative multicomponent analysis. Journal of Applied Crystallography, 7(6), 519-525. doi:10.1107/ S0021889874010375.

Coombs, D. S., Alberti, A., Armbruster, T., Artioli, G., Colella, C. Galli, E., Grice, J. D., Liebau, F., Mandarino, J. A., Minato, H., Nickel, E. H., Passaglia, E., Peacor, D. R., Quartieri, S., Rinaldi, R., Ross, M., Sheppard, R. A., Tillmanns, E. \& Vezzalini, G. (1998). Recommended nomenclature for zeolite minerals: report of the subcommittee on zeolites of the International Mineralogical Association, Commission on New Minerals and Mineral Names. Mineralogical Magazine 62(4), 533-571.

Dal Molin, D. C. C. (2005). Adições minerais para concreto estrutural. En Isaia, G. C. (Ed.), Concreto: Ensino, Pesquisa e Realizações. (Vol 1). pp. 345-379). São Pablo: IBRACON. googlear

Fernández, L. I. \& Trezza, M. A. (2007). Estudio de la Aptitud del Loess Pampeano como Adición Activa al Cemento Portland. Revista de la Construcción, 6(1), 4-12.

IRAM 1505. (2005). Agregados. Análisis granulométrico. Buenos Aires: IRAM.

IRAM 1536. (1978). Hormigón fresco de cemento pórtland. Método de ensayo de la consistencia utilizando el tronco de cono. IRAM: Buenos Aires: IRAM.

IRAM 1546. (2013). Hormigón de cemento. Método de ensayo de compresión. Buenos Aires: IRAM.
IRAM 1627. (1997). Agregados. Granulometría de los agregados para hormigones. Buenos Aires: IRAM.

IRAM 1658. (1995). Hormigón. Determinación de la resistencia a la tracción simple por compresión diametral. Buenos Aires: IRAM.

IRAM 1663. (2002). Hormigón de cemento. Aditivos químicos. Buenos Aires: IRAM.

IRAM 1871. (2004). Hormigón. Método de ensayo para determinar la capacidad y la velocidad de succión capilar de agua del hormigón endurecido. Buenos Aires: IRAM.

IRAM 50000. (2014). Cemento. Cemento para uso general. Composición, características, evaluación de la conformidad y condiciones de recepción. Buenos Aires: IRAM.

Malhotra, V. M. \& Mehta, P. K. (1996). Pozzolanic and cementitious materials. (Vol 1). Amsterdam: Gordon and Breach Publishers.

Najimi, M., Sobhani, J., Ahmadi, B. \& Shekarchi, M. (2012). An experimental study on durability properties of concrete containing zeolite as a highly reactive natural pozzolan. Construction and Building Materials, 35, 1023-1033. doi:10.1016/j.conbuildmat.2012.04.038

Perraki, T., Kontori, E., Tsivilis, S. \& Kakali, G. (2010). The effect of zeolite on the properties and hydration of blended cements. Cement and Concrete Composites, 32(2), 128-133. doi: 10.1016/j.cemconcomp.2009.10.004

Poon, C. S., Lam, L., Kou, S. C. \& Lin, Z. S. (1999). A study on the hydration rate of natural zeolite blended cement pastes. Construction and Building Materials, 13(8), 427-432.

Rahhal, V. \& Eperjesi, L. (2012). Adiciones minerales. En Maldonado, G. N. \& Carrasco, M. F. (Eds.), Ese material llamado hormigón. (pp 79-92). Buenos Aires: Asociación Argentina de Tecnología del Hormigón.

Rosell, M., Galloso, R. \& Calvo, B. (2006). Zeolita como aditivo mineral activo en hormigones de altas prestaciones. Boletín Geológico y Minero, 117(4), 783-792.

Sheppard, R. A. \& Gude, A. J. (1969). Diagenesis of tufts in the Barstow Formation, Mud Hills, San Bernadino County, California. Geological Survey Professional Paper, 634. Washington: U.S. Government Printing Office.

SIA 262/1-E. (2003). Norme Suisse. Construction en béton Spécifications complémentaires, Annexe E: Perméabilité à I'air dans les Structures. Zurich: SIA.

Uzal, B. \& Turanlı, L. (2012). Blended cements containing high volume of natural zeolites: Properties, hydration and paste microstructure. Cement and Concrete Composites, 34(1), 101-109. doi:10.1016/j.cemconcomp.2011.08.009

Yılmaz, B., Uçar, A., Öteyaka, B. \& Uz, V. (2007). Properties of zeolitic tuff (clinoptilolite) blended Portland cement. Building and Environment, 42(11), 3808-3815. doi:10.1016/j. buildenv.2006.11.006 


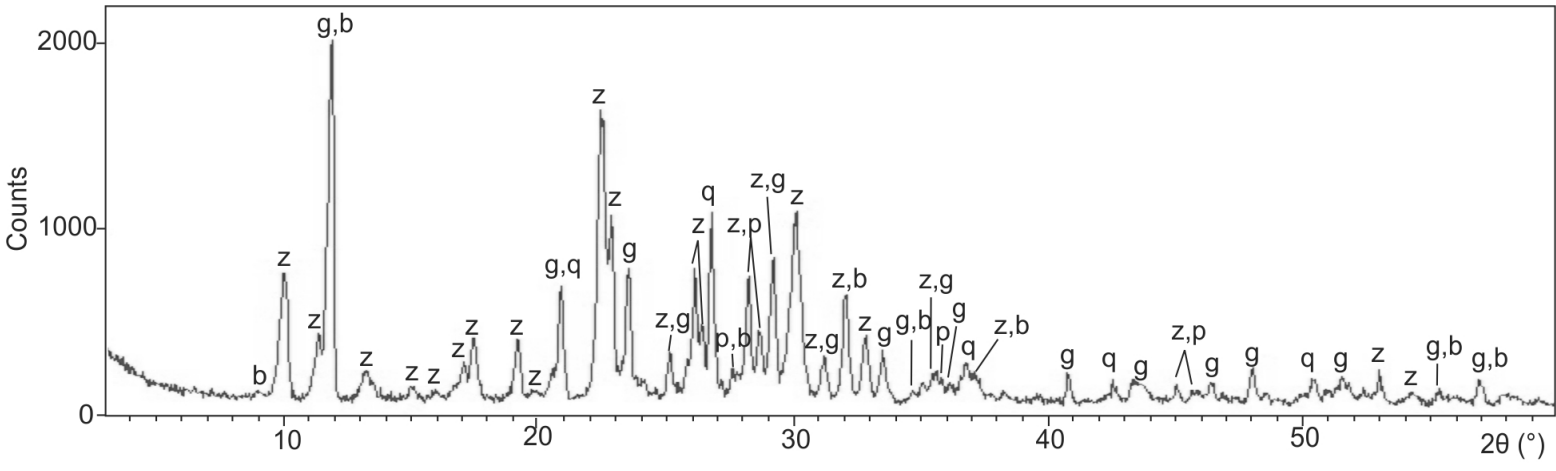

\begin{tabular}{ccccccccccccc}
\multicolumn{7}{l}{ Table 2. Chemical composition (\%) of the pozzolanic material determined by $\mathrm{X}$-ray Fluorescence (LOI: Loss on Ignition). Source: Self-elaboration, 2014.} \\
\hline $\mathrm{SiO} 2$ & $\mathrm{TiO} 2$ & $\mathrm{Al} 2 \mathrm{O} 3$ & $\mathrm{Fe} 2 \mathrm{O} 3$ & $\mathrm{MnO}$ & $\mathrm{MgO}$ & $\mathrm{CaO}$ & $\mathrm{Na} 2 \mathrm{O}$ & $\mathrm{K} 2 \mathrm{O}$ & $\mathrm{P} 2 \mathrm{O} 5$ & LOI & $\mathrm{S}$ & total \\
\hline 59.81 & 0.19 & 14.32 & 1.04 & 0.01 & 0.83 & 5.50 & 5.76 & 1.36 & 0.02 & 7.47 & 3.36 & 99.67 \\
\hline
\end{tabular}

\begin{tabular}{|c|c|c|c|c|c|c|c|c|c|c|}
\hline Material / Concrete & ZOO & ZO5 & ZO10 & ZO15 & $\mathrm{ZO} 20$ & ZCO & ZC5 & ZC10 & ZC15 & ZC20 \\
\hline Cement OPC 40 & 450.0 & 427.5 & 405.0 & 382.5 & 360.0 & - & - & - & - & - \\
\hline Cement CPC 40 & - & - & - & - & - & 450.0 & 427.5 & 405.0 & 382.5 & 360.0 \\
\hline Water & 185.0 & 185.0 & 185.0 & 185.0 & 185.0 & 185.0 & 185.0 & 185.0 & 185.0 & 185.0 \\
\hline Addition (Zeolite) & - & 22.5 & 45.0 & 67.5 & 90.0 & - & 22.5 & 45.0 & 67.5 & 90.0 \\
\hline Coarse Aggregate & 972.5 & 967.6 & 962.6 & 957.7 & 952.7 & 972.5 & 967.6 & 962.6 & 957.7 & 952.7 \\
\hline Fine Aggregate & 840.3 & 836.0 & 831.8 & 827.5 & 823.2 & 840.3 & 836.0 & 831.8 & 827.5 & 823.2 \\
\hline $\begin{array}{l}\text { Plasticizer } \quad \text { Additive } \\
(0,35 \% \mathrm{MA})\end{array}$ & 1.6 & 1.6 & 1.6 & 1.6 & 1.6 & 1.6 & 1.6 & 1.6 & 1.6 & 1.6 \\
\hline$w / c$ ratio & 0.41 & 0.43 & 0.46 & 0.48 & 0.51 & 0.41 & 0.43 & 0.46 & 0.48 & 0.51 \\
\hline w/bm ratio & 0.41 & 0.41 & 0.41 & 0.41 & 0.41 & 0.41 & 0.41 & 0.41 & 0.41 & 0.41 \\
\hline
\end{tabular}

\begin{tabular}{|c|c|c|c|c|c|c|c|c|c|c|}
\hline Concrete Samples & $\mathrm{ZOO}$ & ZO5 & ZO10 & ZO15 & ZO20 & $\mathrm{ZCO}$ & ZC5 & ZC10 & ZC15 & ZC20 \\
\hline Splitting Tensile [MPa] & 4.5 & 3.8 & 3.8 & 4.2 & 4.5 & 3.9 & 3.9 & 3.2 & 3.8 & 3.8 \\
\hline Elastic modulus [GPa] & 38.2 & 37.2 & 35.8 & 39.2 & 37.2 & 38.7 & 37.9 & 38.1 & 35.6 & 34.1 \\
\hline
\end{tabular}

\begin{tabular}{|c|c|c|c|c|c|c|c|c|c|c|}
\hline Concrete samples & $\mathrm{ZOO}$ & ZO5 & ZO10 & ZO15 & $\mathrm{ZO} 20$ & $\mathrm{ZCO}$ & ZC5 & ZC10 & ZC15 & ZC20 \\
\hline Water absorption [\%] & 3.9 & 3.4 & 4.3 & 3.8 & 3.9 & 6.5 & 6.8 & 7.3 & 7.6 & 8.3 \\
\hline Capillary Suction [gr/m2] & 4133.8 & 4145.1 & 4549.7 & 4224.3 & 3491.5 & 7039.6 & 7444.2 & 7888.4 & 8143.1 & 8626.9 \\
\hline $\begin{array}{l}\text { Capillary Suction speed } \\
\text { [gr/m2.s1/2] }\end{array}$ & 8.4 & 8.7 & 9.9 & 8.5 & 6.7 & 15.9 & 14.1 & 17.5 & 18.4 & 19.5 \\
\hline Air permeability [kT] & 0.33 & 1.37 & 2.58 & 0.33 & 0.16 & 3.40 & 3.55 & 3.75 & 3.48 & 5.88 \\
\hline
\end{tabular}

